\title{
URINARY CONCENTRATING ABILITY IN PREGNANT WOMEN WITH ASYMPTOMATIC BACTERIURIA*
}

\author{
By ALAN L. KAITZ \\ (From the Department of Medicine, Harvard Medical School, and the Medical Research \\ Department of the Yamins Research Laboratory and the Medical Service, \\ Beth Israel Hospital, Boston, Mass.)
}

(Submitted for publication February 2, 1961 ; accepted March 13, 1961)

Studies of patients with acute and chronic pyelonephritis have suggested that impairment of urinary concentrating ability may be an early feature of this disease (1-3). In these reports the diagnostic criteria for pyelonephritis have included clinical and pyelographic findings together with an abnormal urinary sediment with or without positive cultures. More recently, increasing emphasis has been placed on significant bacteriuria determined by quantitative urine cultures as a criterion for active pyelonephritis (4). In some subjects in whom bacteriuria has been discovered for the first time by quantitative urine cultures, the diagnosis of pyelonephritis has then been established from the clinical and laboratory findings (5); but in other individuals with asymptomatic bacteriuria, the normal urinary sediment and pyelographic findings, and even postmortem microscopic examination of the kidneys, have not supported a clinical suspicion of silent pyelonephritis $(5,6)$.

The present study was undertaken to determine whether an abnormality in concentrating ability might exist in healthy individuals with numerically significant bacteria in the urine. Pregnant women were chosen for study, since the incidence of bacteriuria is reported to be high in this group ( 7$)$, whereas conditions known to impair concentrating ability, such as malnutrition, electrolyte disturbances and degenerative renal diseases, would not be encountered commonly among young, pregnant women. The present report concerns the finding of impaired urinary concentrating ability following 24 hours of fluid deprivation in pregnant women

\footnotetext{
* This investigation was supported by research grants from the National Institutes of Health, Bethesda, Md., the American Heart Association, and the Life Insurance Medical Research Fund. This paper was presented (in part) at the National Meeting of the American Federation for Clinical Research, Atlantic City, N. J., May 1, 1960.
}

with asymptomatic bacteriuria, compared with a suitable control group.

\section{METHODS}

The subjects were healthy, pregnant women attending the Beth Israel Hospital Prenatal Clinic. A detailed report concerning bacteriuria and pyelonephritis in this group has been presented elsewhere (8). The technique used to obtain clean-voided urine cultures was as follows. The perineum was cleansed with sponges immersed in a $1: 1,000$ solution of benzalkonium chloride. A voided specimen was then collected in a sterile bottle and promptly refrigerated. Within 24 hours quantitative urine cultures were performed with limited identification of those bacteria appearing in significant numbers as described previously (5). Pregnant women whose cultures revealed approximately 100,000 or more bacteria per $\mathrm{ml}$ in a random, clean-voided urine specimen obtained at the first clinic visit were requested to return for a repeat culture. If the second, random, cleanvoided urine specimen again contained 100,000 or more bacteria per $\mathrm{ml}$ a 24 hour fluid-deprivation concentration test was carried out. Subjects were told that a urinary tract infection might be present and were instructed to refrain from all fluids from breakfast on one day until after completion of the test the next morning: dry meals were permitted. Initially only a single, clean-voided urine specimen for culture and determination of osmolality was obtained at the termination of the 24 hours of dehydration. Later in the study a 24 hour urine collection during the period of dehydration was also obtained for determination of the endogenous creatinine clearance and the osmolal clearance. Subjects were asked to keep the 24 hour urine collection refrigerated; no preservatives were used. A venous blood specimen was obtained at the end of the period of dehydration for determination of creatinine and osmolality. All samples were refrigerated until analyzed. Osmolality determinations were performed within 24 hours for most specimens.

Pregnant women of age and duration of pregnancy comparable to those with bacteriuria, but with low bacterial counts in clean-voided urine specimens, were chosen as control subjects. It was difficult to match the groups exactly with respect to parity since the incidence of bacteriuria rose sharply with the number of prior pregnancies $(7,8)$. However, as many: grandmultiparous 


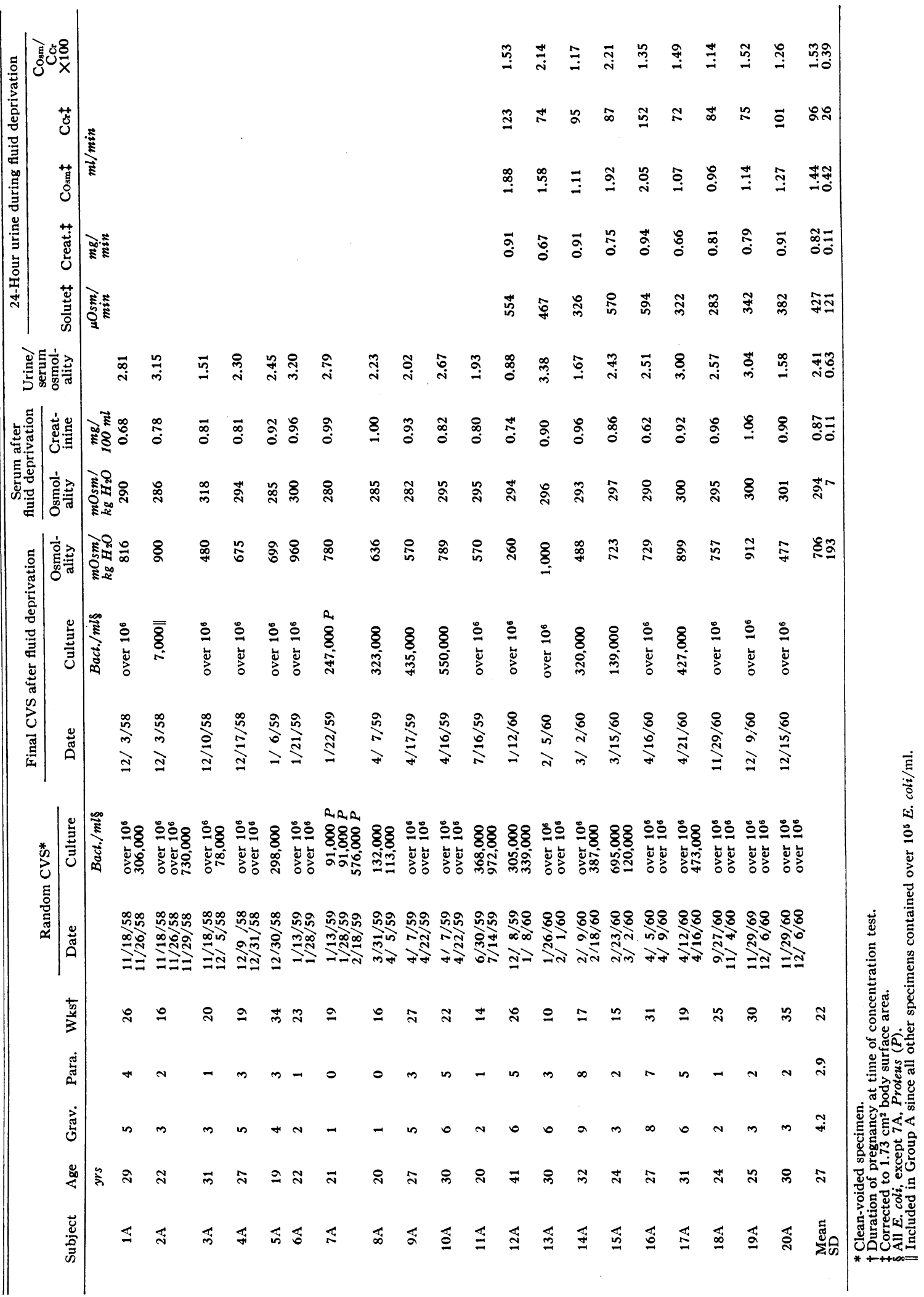


control subjects as could be obtained were included to make the groups as comparable as possible. To provide a similar incentive to refrain from fluids for 24 hours, all women were told that a urinary tract infection might be present.

Osmolalities were measured with a Fiske osmometer. Creatinine was determined by the method of Brod and Sirota (9). Since endogenous serum creatinine levels are low in pregnancy (10), a known amount of creatinine was added to some specimens to bring the photometric readings into a more desirable range, and this amount was substracted from the final calculation.

\section{RESULTS}

The results are considered separately for three different groups of subjects. The first group (A) was composed of 20 women whose urine specimens persistently contained over 100,000 gramnegative bacteria per $\mathrm{ml}$, usually $E$. coli; none was encountered with persistently high counts of gram-positive organisms. These 20 women were considered to have bacteriuria indicative of bacterial multiplication within the urinary tract. Data for this group are shown in Table I. The second group (B) were 30 women whose urine specimens repeatedly contained fewer than 100,000 bacteria per $\mathrm{ml}$. These organisms were presumed to represent contamination. Women with persistently low-count urine cultures were not considered to have bacteriuria and served as a control for Group A. Data for this low-count control group are shown in Table II. The third group (C) included 20 subjects whose urine specimens had more than 100,000 bacteria per $\mathrm{ml}$ on one occasion, whereas other specimens from the same individual at other times contained small numbers of bacteria. In general, the bacteria in Group $\mathrm{C}$ were grampositive, varied considerably in kind and concentration, and most likely represented contamination rather than true bacteriuria. However, occasionally gram-negative bacteria appeared in large numbers in one or more specimens and it was difficult to distinguish excessive contamination from transient bacteriuria. Data for Group C subjects are presented in Table III.

Women with asymptomatic bacteriuria (Table I) had significant impairment of urinary concentrating ability compared with control subjects in Group B without bacteriuria (Table II). Serum osmolality values after 24 hours' dehydration were the same in both groups. Nine of the 20 women in Group A had urinary osmolality values below $700 \mathrm{mOsm}$ per $\mathrm{kg} \mathrm{H}_{2} \mathrm{O}$ in the final specimen following dehydration; none of the women in the control Group B showed this degree of impairment. Subjects in Group $C$ with occasional high bacterial counts in the urine, probably due to contamination, had maximal urinary osmolality values after 24 hours' dehydration, similar to those for control Group B. The impairment in concentrating ability observed in women with asymptomatic bacteriuria was highly significant $(p<$ 0.01) compared with the control Group $B$, both with respect to the mean maximal urinary osmolality (706 mOsm per $\mathrm{kg} \mathrm{H}_{2} \mathrm{O}$ for Group A, compared with 935 mOsm per $\mathrm{kg} \mathrm{H}_{2} \mathrm{O}$ in Group B) or the mean maximal urine/serum osmolality ratio (2.41 for Group A compared with 3.16 for Group B). Except for the subject with the severest impairment (Subject 12 in Group A), symptoms of urinary frequency or nocturia did not reflect the degree of impairment of concentrating ability in the 24 hour concentration test.

Serum creatinine concentrations determined in all 20 women with bacteriuria in Group $A$ and in 21 women in the control Group B did not differ significantly. Timed urine specimens during the 24 hour period of dehydration were obtained from 9 women in Group A and 19 women in Group B. The rates of solute excretion and osmolal clearance averaged about 9.5 per cent higher in the Group A women with bacteriuria, but these differences were not significant. The endogenous creatinine clearance averaged about 20 per cent lower in the bacteriuric group $(0.05>$ $p>0.02)$. The combined effects of a slightly higher osmolal clearance and slightly lower creatinine clearance resulted in a significantly higher percentage of filtered solute which was excreted for Group $A$ as calculated from the ratio $\mathrm{C}_{\mathrm{Osm}} /$ $\mathrm{C}_{\mathrm{Cr}} \times 100$ (mean value 1.53 for Group A, 1.10 for Group $\mathrm{B}, t=2.98, \mathrm{p}<0.01)$. However, the maximal urine osmolality following fluid deprivation was not correlated with the $\mathrm{C}_{\mathrm{Osm}} / \mathrm{C}_{\mathrm{Cr}}$ ratio.

Hypokalemia, hypercalcemia, and sickle cell disease, conditions known to be associated with impaired concentrating ability, were not present in these subjects. It is emphasized that women with bacteriuria as a group could not be distinguished from those without bacteriuria on the basis of history, physical examination (including blood pressure), pyuria, or proteinuria (8). 


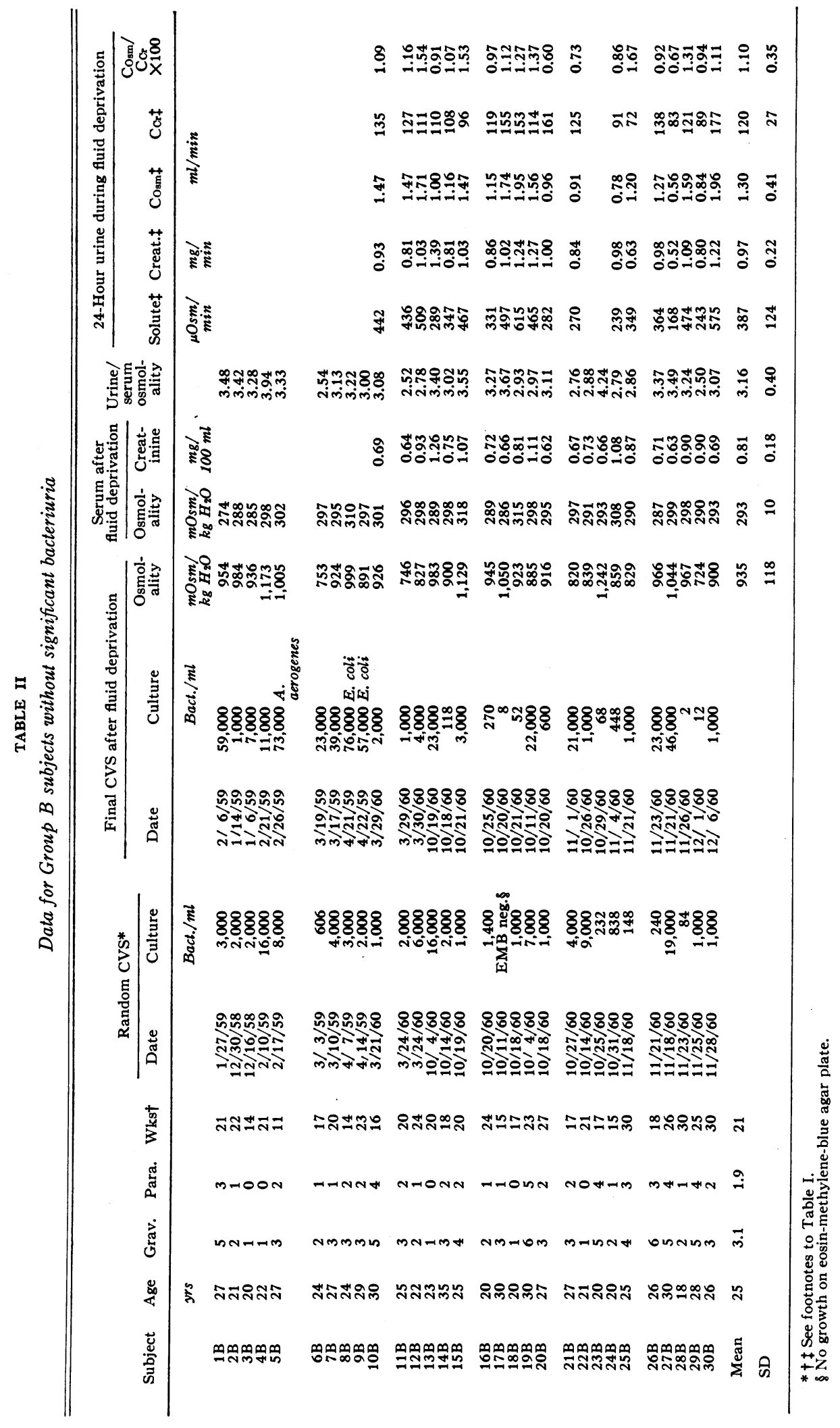


BACTERIURIA AND URINARY CONCENTRATING ABILITY IN PREGNANCY

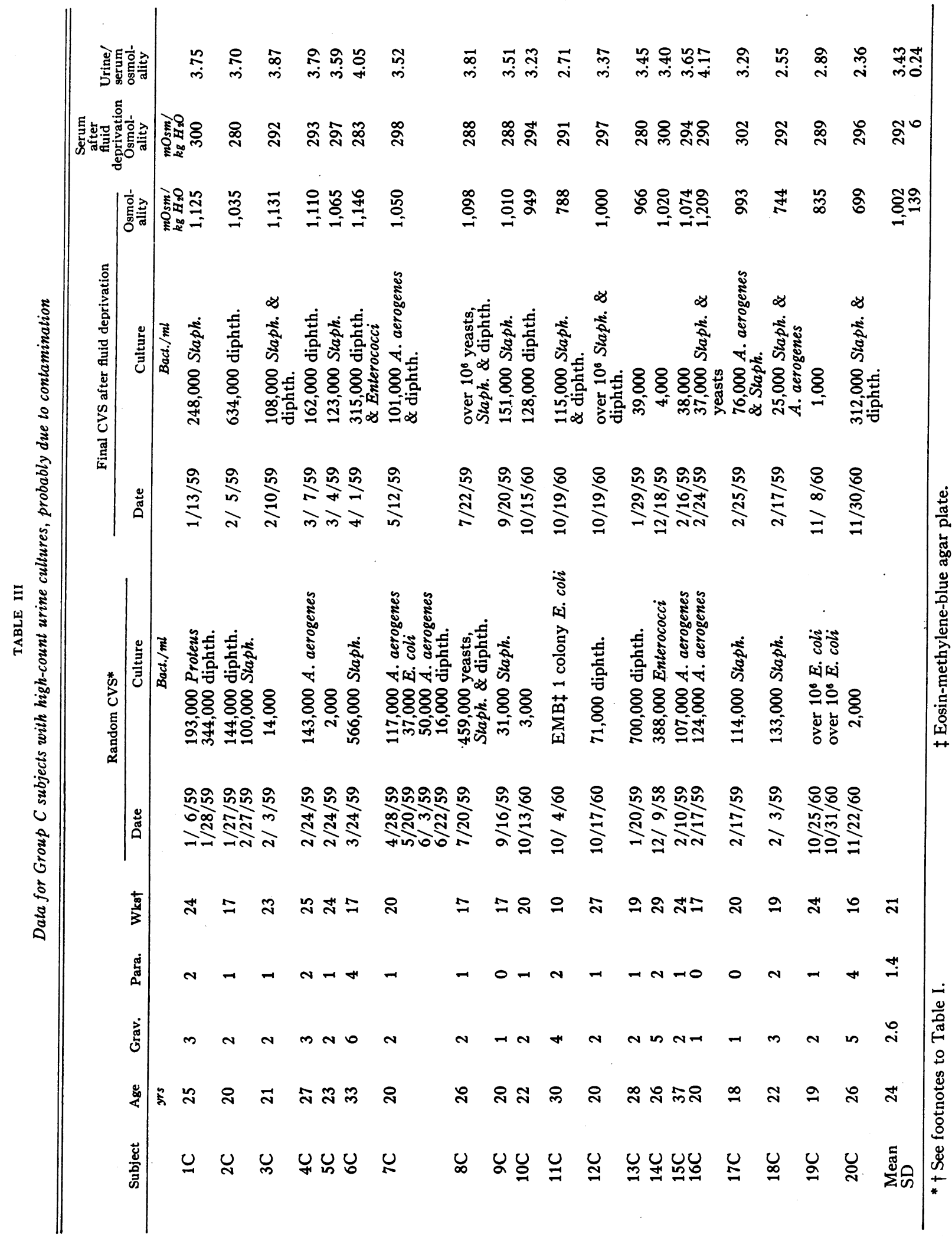


TABLE IV

Routine urinalysis at first prenatal clinic visit for Group A subjects with bacteriuria (see Table I)

\begin{tabular}{|c|c|c|c|c|c|c|c|c|}
\hline \multirow[b]{2}{*}{ Subject } & \multirow[b]{2}{*}{ Date } & \multirow[b]{2}{*}{ Sp gr } & \multirow[b]{2}{*}{ Protein* } & \multirow[b]{2}{*}{ Sugart } & \multicolumn{4}{|c|}{ Urinary sediment } \\
\hline & & & & & WBC & $\mathrm{RBC}$ & Casts & Bact.f \\
\hline & & & & & \multicolumn{4}{|c|}{ no./high-powered field } \\
\hline $1 \mathrm{~A}$ & $11 / 18 / 58$ & qns & 0 & 0 & $8-16$ & 0 & 0 & $4+$ \\
\hline $2 \mathrm{~A}$ & $11 / 18 / 58$ & 1.022 & 0 & 0 & 0 & 0 & 0 & $3+$ \\
\hline $3 \mathrm{~A}$ & $11 / 18 / 58$ & 1.012 & 0 & 0 & occ. & $0-2$ & 0 & $3+$ \\
\hline $4 \mathrm{~A}$ & $12 / 9 / 58$ & 1.020 & 0 & 0 & occ. & occ. & 0 & $3+$ \\
\hline $5 \mathrm{~A}$ & $12 / 30 / 58$ & qus & 0 & 0 & $1-3$ & occ. & 0 & $4+$ \\
\hline $6 \mathrm{~A}$ & $1 / 13 / 59$ & 1.023 & 0 & 0 & occ. & 0 & 0 & $3+$ \\
\hline $7 \mathrm{~A}$ & $1 / 13 / 59$ & 1.015 & 0 & 0 & 0 & 0 & 0 & 0 \\
\hline $8 \mathrm{~A}$ & $3 / 31 / 59$ & 1.012 & 0 & 0 & 0 & 0 & 0 & $4+$ \\
\hline $9 \mathrm{~A}$ & $4 / 7 / 59$ & 1.012 & 0 & 0 & $1-3$ & 0 & 0 & $4+$ \\
\hline $10 \mathrm{~A}$ & $4 / 7 / 59$ & 1.020 & 0 & 0 & $8-10$ & 0 & 0 & $1+$ \\
\hline $11 \mathrm{~A}$ & $6 / 30 / 59$ & 1.020 & 0 -tr. & 0 & occ. & 0 & 0 & $3+$ \\
\hline $12 \mathrm{~A}$ & $12 / 8 / 59$ & 1.007 & 0 & 0 & $20-25$ & occ. & 0 & $1+$ \\
\hline $13 \mathrm{~A}$ & $1 / 26 / 60$ & 1.028 & 0 & 0 & 0 & 0 & 0 & \\
\hline $14 \mathrm{~A}$ & $2 / 9 / 60$ & 1.008 & 0 & $\mathbf{0}$ & 0 & 0 & 0 & $1+$ \\
\hline $15 \mathrm{~A}$ & $2 / 23 / 60$ & 1.011 & 0 & 0 & 0 & 0 & 0 & $1+$ \\
\hline $16 \mathrm{~A}$ & $4 / 5 / 60$ & 1.010 & 0 & 0 & 0 & 0 & 0 & $4+$ \\
\hline $17 \mathrm{~A}$ & $4 / 12 / 60$ & 1.014 & 0 & 0 & 0 & 0 & 0 & $3+$ \\
\hline $18 \mathrm{~A}$ & $9 / 27 / 60$ & 1.016 & 0 & 0 & many & 0 & 0 & $2+$ \\
\hline $19 \mathrm{~A}$ & $11 / 29 / 60$ & 1.016 & 0 & 0 & $14-16$ & 0 & 0 & $1+$ \\
\hline $20 \mathrm{~A}$ & $12 / 15 / 60$ & qns & $1-2+$ & 0 & many & $0-1$ & 0 & $4+$ \\
\hline
\end{tabular}

* Prior to 1960 , beta naphthalene sulfonic acid precipitation method; since 1960, using Uristix.

$\dagger$ Prior to 1960, using Clinitest; since 1960, using Uristix.

$\ddagger$ Graded qualitatively, 0 to $4+$.

Routine analyses at the first clinic visit for the 20 Group A subjects with bacteriuria are recorded in Table IV. Cylinduria was absent, pyuria was variable, and slight proteinuria was present in 2 women.

\section{DISCUSSION}

The validity of classifying subjects as having bacteriuria or not on the basis of bacterial counts in clean-voided specimens deserves comment. The basis for such a classification rests on the assumption that if bacteria are present within the urinary tract they will multiply to large numbers in the bladder urine which serves as a good culture medium. In contrast, bacteria added to sterile urine as contamination in clean-voided specimens usually are considerably fewer in number. In general, this hypothesis has been verified $(4-6,11-20)$, and exceptions clearly outlined (21), but agreement has not been universal $(22,23)$. The choice of the number of bacteria as a dividing line between bacteriuria and contamination is based on statistical probabilities. In agreement with many other workers in this field, I have found 100,000 bacteria per $\mathrm{ml}$ to represent a reasonable dividing line sufficiently sensitive to include most instances of bacteriuria and yet discriminatory against most instances of contamination. For example (8), in 33 pregnant women with over 100,000 gramnegative bacteria per $\mathrm{ml}$ in an initial random, cleanvoided urine specimen, a second clean-voided urine culture gave the same result in 21 women (63.6 per cent). After two successive cultures showing over 100,000 gram-negative bacteria per $\mathrm{ml}$, a third culture, or more, gave the same result in over 85 per cent of the women. Thus, the chances that women in Group A in this study, with a minimum of two and usually three separate cultures containing over 100,000 gram-negative bacteria per $\mathrm{ml}$, would remain in this high-count group with additional cultures would be about 85 per cent. The high-count urine cultures for subjects in Group C, however, were considered to represent contamination, since additional cultures were not confirmatory. The finding of normal concentrating ability in these Group $C$ subjects is in accord with this interpretation.

The finding of definite impairment in concentrating ability (maximal urinary osmolality less than $700 \mathrm{mOsm}$ per $\mathrm{kg} \mathrm{H}_{2} \mathrm{O}$ ) with fluid deprivation in 9 of 20 pregnant women with asympto- 
matic bacteriuria may be a reflection of early silent pyelonephritis in these subjects. In Subject $9 \mathrm{~A}$, with bacteriuria and a maximal urine osmolality of $570 \mathrm{mOsm}$ per $\mathrm{kg} \mathrm{H}_{2} \mathrm{O}$ during pregnancy, studies 7 months post partum revealed improvement in concentrating ability to $800 \mathrm{mOsm}$ per $\mathrm{kg} \mathrm{H}_{2} \mathrm{O}$ in association with spontaneous cessation of bacteriuria. However, symptomatic, acute pyelonephritis developed in this subject 8 months post partum, which was not treated, and at 8.5 months post partum maximal urinary osmolality was again reduced to $620 \mathrm{mOsm}$ per $\mathrm{kg} \mathrm{H}_{2} \mathrm{O}$ with return of $E$. coli bacteriuria. Treatment to suppress bacteriuria then resulted in improvement in maximal urinary osmolality to $870 \mathrm{mOsm}$ per $\mathrm{kg} \mathrm{H}_{2} \mathrm{O}$ at 10 months post partum. In Subject $8 \mathrm{~A}$, both bacteriuria with $E$. coli and impaired concentrating ability persisted post partum (maximal urine osmolality $636 \mathrm{mOsm}$ per $\mathrm{kg} \mathrm{H}_{2} \mathrm{O}$ during pregnancy, $725 \mathrm{mOsm} 2$ months post partum). Spontaneous clearing of bacteriuria post partum in Subject 15A was associated with improvement in concentrating ability from a maximal urinary osmolality of $723 \mathrm{mOsm}$ per $\mathrm{kg} \mathrm{H}_{2} \mathrm{O}$ during pregnancy to $1,000 \mathrm{mOsm} 3.5$ months post partum. These few serial studies suggest that impaired concentrating ability may be a reversible result of infection rather than a pre-existing, fixed defect which predisposes to infection. Similarly, Winberg (3) has reported that impaired concentrating ability occurring with acute, nonobstructive urinary tract infections in children possibly lasted for 4 to 6 weeks after symptoms and urinary findings cleared. The presence of silent pyelonephritis in pregnant women with asymptomatic bacteriuria is also suggested by their high incidence of the subsequent development of acute pyelonephritis $(7,8)$. Impaired concentrating ability with bacteriuria may also be attributed to an increase in the hydronephrosis of pregnancy due to ureteritis and ureteral reflux in the absence of renal infection, but a clear distinction between pyelonephritis and infection limited to the ureter cannot easily be made.

It is possible that screening for both bacteriuria and impaired concentrating ability might effectively select those individuals destined to develop acute pyelonephritis of pregnancy. This is supported by the subsequent development of acute pyelonephritis in Subjects 9A, 10A, 12A and
$18 \mathrm{~A}$, all with some degree of impairment of concentrating ability and bacteriuria, whereas in the remaining subjects in Group A, symptomatic pyelonephritis during pregnancy did not occur. If the incidence of bacteriuria among pregnant women is taken as 5 per cent $(7,8)$ and 40 per cent of such women have impaired concentrating ability, then silent pyelonephritis might be present in about 2.0 per cent of all pregnant women. Long-term studies are clearly indicated to determine whether chronic pyelonephritis develops in pregnant women with asymptomatic bacteriuria.

The mechanism by which impaired concentrating ability occurs with asymptomatic bacteriuria is not clear from the limited data obtained. The creatinine clearance values are somewhat low in both Groups A and B. This may reflect incompleteness of the collections and use of a less specific method for serum creatinine or the effect of upright posture during most of the collection period. In view of the relatively normal serum creatinine concentrations and endogenous creatinine clearances, severe reduction in glomerular filtration rate (GFR) appears unlikely, although it is possible that one kidney may have been affected more than the other. It is known that small reductions in filtration rate may affect the concentrating mechanism (24). The slightly higher solute excretion in bacteriuric women may be an artifact, since it is not certain that all women kept the 24 hour urine collection refrigerated. Osmolality of urine specimens left at room temperature has been observed to rise and this process may be accelerated in the presence of large numbers of bacteria. Additional and serial renal function studies are necessary to define the interrelation of GFR, solute excretion and concentrating ability in subjects with bacteriuria.

Calculation of food intake was made by dietitians for all the women in this study and showed no difference for women with and without bacteriuria. Weight gain during pregnancy was comparable for both groups. Thus, it is unlikely that protein deprivation was an important factor in the development of impaired concentrating ability.

An experimental model was sought to study the effects of renal infection on the concentrating mechanism. Bacteriuria and pyelonephritis were produced by the direct injection of a strain of Proteus into the urinary bladder of the rat (25). 
Impaired concentrating ability was observed, but the animals were severely uremic. Attempts to produce bacteriuria without altering GFR in order to study the direct effects of infection on the concentrating mechanism have not yet been successful. Even in experimental, unilateral pyelonephritis, which prevents the development of uremia, the involved side has shown reduction in filtration rate (26).

\section{SUM MARY}

1. Pregnant women with asymptomatic bacteriuria were found to have significant impairment of urinary concentrating ability when compared with a control group without bacteriuria.

2. Impaired concentrating ability most likely is secondary to silent, active pyelonephritis.

3. The mechanism of the impairment remains to be determined. Direct involvement of the renal concentrating mechanism by infection, an increase in the hydronephrosis of pregnancy due to infection and malfunction of the ureters, and changes in the concentrating mechanism secondary to slight reductions in glomerular filtration rate may be important factors.

\section{REFERENCES}

1. Brod, J. Chronic pyelonephritis. Lancet 1956, 1, 973.

2. Kleeman, C. R., Hewitt, W. L., and Guze, L. B. Pyelonephritis. Medicine (Baltimore) 1960, 39, 3.

3. Winberg, J. Renal function studies in infants and children with acute, nonobstructive urinary tract infections. Acta paediat. (Uppsala) 1959, 48, 577.

4. Kass, E. H. Asymptomatic infections of the urinary tract. Trans. Ass. Amer. Phycns 1956, 69, 56.

5. Kaitz, A. L., and Williams, E. J. Bacteriuria and urinary-tract infections in hospitalized patients. New Engl. J. Med. 1960, 262, 425.

6. MacDonald, R. A., Levitin, H., Mallory, G. K., and Kass, E. H. Relation between pyelonephritis and bacterial counts in urine: An autopsy study. New Engl. J. Med. 1957, 256, 915.

7. Kass, E. H. Bacteriuria and pyelonephritis of pregnancy. A. M. A. Arch. intern. Med. 1960, 105, 194.

8. Kaitz, A. L. Bacteriuria and pyelonephritis of pregnancy. New Engl. J. Med. In press.

9. Brod, J., and Sirota, J. H. The renal clearance of endogenous "creatinine" in man. J. clin. Invest. 1948, 27, 645.

10. Sims, E. A. H., and Krantz, K. E. Serial studies of renal function during pregnancy and puerperium in normal women. J. clin. Invest. 1958, 37, 1764.
11. Sanford, J. P., Favour, C. B., Mao, F. H., and Harrison, J. H. Evaluation of "positive" urine culture: Approach to differentiation of significant bacteria from contaminants. Amer. J. Med. 1956, $20,88$.

12. Jackson, G. G., Grieble, H. G., and Knudsen, K. B. Urinary findings diagnostic of pyelonephritis. J. Amer. med. Ass. 1958, 166, 14.

13. Riley, H. D., Jr., and Knight, V. Urinary tract infections in paralytic poliomyelitis. Medicine (Baltimore) 1958, 37, 281.

14. Monzon, O. T., Ory, E. M., Dobson, H. L., Carter, E., and Yow, E. M. Comparison of bacterial counts of urine obtained by needle aspiration of bladder, catheterization and midstream-voided methods. New Engl. J. Med. 1958, 259, 764.

15. Riley, H. D., Jr. Evaluation of method for detecting and following urinary tract infections in females without catheterization. J. Lab. clin. Med. 1958, $52,840$.

16. Boshell, B. R., and Sanford, J. P. Screening method for evaluation of urinary tract infections in female patients without catheterization. Ann. intern. Med. 1958, 48, 1040.

17. Pryles, C. V., and Steg, N. L. Specimens of urine obtained from young girls by catheter versus voiding: Comparative study of bacterial cultures, gram stains, and bacterial counts in paired specimens. Pediatrics 1959, 23, 441.

18. Switzer, S. Clean-voided urine culture in surveying populations for urinary tract infection. J. Lab. clin. Med. 1960, 55, 557.

19. Rengarts, R. T. Asymptomatic bacilluria in sixtyeight diabetic patients. Amer. J. med. Sci. 1960, 239, 159.

20. Kunin, C. M., Southall, I., and Paquin, A. J. Epidemiology of urinary-tract infections: A pilot study of 3057 school children. New Engl. J: Med. 1960, 263, 817.

21. Kass, E. H. Chemotherapeutic and antibiotic drugs in the management of infections of the urinary tract. Amer. J. Med. 1955, 18, 764.

22. Birchall, R. Pyelonephritis-An enigma. Amer. J. Med. 1960, 28, 501.

23. Seneca, H., Troc, O. K., and Peer, P. Identification of true pathogens of urinary tract: Criteria and methods. J. Urol. (Baltimore) 1960, 84, 499.

24. Levinsky, N. G., Davidson, D. G., and Berliner, R. W. Effects of reduced glomerular filtration rate on urine concentration in the presence of antidiuretic hormone. J. clin. Invest. 1959, 38, 730.

25. Vivaldi, E., Cotran, R., Zangwill, D. P., and Kass, E. H. Ascending infection as a mechanism in the pathogenesis of experimental non-obstructive pyelonephritis. Proc. Soc. exp. Biol. (N. Y.) 1959, 102, 242.

26. Bricker, N. S., Dewey, R. R., Lubowitz, H., Stokes, J., and Kirkensgaard, T. Observations on the concentrating and diluting mechanisms of the diseased kidney. J. clin. Invest. 1959, 38, 516. 